\title{
植物凯氏带化学成分、生理功能及相关调控 机制的研究进展
}

崔亚宁 ${ }^{1,2}$, 满奕 $^{1,2}$, 宋程威 ${ }^{1,2}, 弓$ 曦 $^{1,2}$, 钱虹萍 ${ }^{1,2}$, 林金星 ${ }^{1,2 *}$

1. 北京林业大学林木分子设计育种高精尖创新中心, 北京 100083 ;

2. 北京林业大学生物科学与技术学院, 北京 100083

* 联系人, E-mail: linjx@ibcas.ac.cn

收稿日期：2019-06-11; 接受日期：2019-11-22; 网络版发表日期：2020-02-11

中国博士后科学基金特别资助项目(批准号: 2019T120056)和国家自然科学基金中德合作项目(批准号: 31761133009)资助

摘要凯氏带是一种环绕在内皮层细胞径向壁和横向壁上的木质化和木栓化带状增厚结构. 凯氏带作为一种保 护性屏障, 不仅可以调节物质和水分在维管束与皮层细胞之间的渗透性流动, 而且在抵御盐胁迫、生物胁迫以及 营养物质的选择性吸收等方面也发挥重要作用. 随着近年来生物化学分析技术及遗传学研究方法的发展, 凯氏带 的相关研究取得了极大进展. 本文简要概述了凯氏带在植物体内的组织结构、化学组成和发育过程, 并重点对凯 氏带生理功能、重要调控基因及其相关调控机制等方面的最新进展进行了总结，以期为凯氏带的深入研究和开 发利用提供参考.

关键词凯氏带, 化学成分, 生理功能, 调控机制

凯氏带(Casparian strip)是高等植物内皮层细胞径 向壁和横向壁上木栓化和木质化的带状增厚结构，它 调控皮层和维管柱之间的物质运输 ${ }^{[1]}$. 在前期工作中, 研究者相继在不同的植物中发现了凯氏带, 包括单子 叶植物、双子叶植物、裸子植物和蕨类植物. 凯氏带 结构的出现, 被认为是植物对陆地环境多变的一种适 应 $^{[2,3]}$. 凯氏带的特化结构可以阻止并抑制皮层与中柱 之间的质外体运输途径，使进入中柱的溶质只能通过 共质体途径, 因此对根部水分及营养物质的吸收有着 极其重要的生物学意义. 凯氏带含有木质素等化学组 分，在阻挡水、离子自由进出植物体的同时，也能够 减少或防止体内向外释放氧气，具有保护植物生理功
能的重要作用 ${ }^{[4,5]}$. 已有研究证实, 凯氏带在植物抵抗 干旱、洪涝灾害和离子胁迫等过程中发挥重要作用. 因此, 深入理解凯氏带的生理功能及调控机制, 可为植 物的抗性研究提供重要的理论依据.

近年来, 随着凯氏带相关研究的不断深入, 凯氏带 的生理功能及调控机制已成为植物质外体屏障研究的 热点. 随着观察技术、化学鉴定方法和基因功能等研 究技术的不断更新 ${ }^{[6]}$, 凯氏带的基本化学成分及影响 其结构形成的因素也逐渐被人们所熟知. 本文简要概 述了凯氏带的组成结构、化学成分和发育过程等3方 面的研究进展, 并重点总结了凯氏带的生理功能及其 形成过程中的调控机制. 同时，对目前凯氏带研究中

引用格式: 崔亚宁, 满奕, 宋程威, 等. 植物凯氏带化学成分、生理功能及相关调控机制的研究进展. 中国科学: 生命科学, 2020, 50: 102-110 Cui Y N, Man Y, Song C W, et al. Chemical components, physiological functions and regulation mechanism of plant Casparian strips (in Chinese). Sci Sin Vitae, 2020, 50: 102-110, doi: 10.1360/SSV-2019-0205 
存在的问题及未来的研究方向进行了简要的讨论和 展望.

\section{1 凯氏带的结构和化学成分}

\section{1 凯氏带的结构}

1865年, 德国植物学家Robert Caspary在植物根部 内皮层的细胞壁上发现了一种增厚结构, 直到20世纪, 这些增厚的结构才被正式命名为凯氏带(Casparian strip). 凯氏带是植物初生根内皮层中最靠近维管柱的 一层细胞结构，环绕细胞一周，呈带状分布并与质膜 紧密结合(图1). 从植物根系的横切面上观察，只能在 相邻细胞的径向壁上发现增厚的点状结构, 研究人员 将其命名为凯氏点(Casparian dots). 此外, 在电子显微 镜下可以观察到, 凯氏带的径向壁具有波浪状起伏, 而 紧靠凯氏带下面的细胞质膜结构较其他部位更厚且更 为平滑, 这种起伏现象是凯氏带在机械功能方面的一 种适应性，随物种和组织分布的不同而有所差异. 质 壁分离实验表明，高渗条件下不能将细胞质膜和凯氏 带分开，这种独特的现象称为“带外质壁分离”(band plasmolysis). 这种现象的产生与胞间连丝无关，可能 是质膜上的类脂或膜蛋白的疏水部分与凯氏带中疏水 性结构相互作用的结果.

凯氏带作为植物的外层屏障, 具有类似生理栅栏 和阀门的功能，控制水分和矿质离子进入维管组织, 防御非生物胁迫和有毒化合物的渗入 ${ }^{[7]}$. 随着研究的 不断深入, 不同植物体中关于凯氏带的结构研究也有 新发现. 例如玉米(Zea mays)中发现五面增厚的U形凯 氏带, 即内切向壁出现加厚现象 ${ }^{[8]}$; 百合属 (Lilium) 的大 部分植物内皮增厚细胞甚至发展成六面 ${ }^{[9]}$. 通常凯氏 带出现在植物初生根的内皮层中，但也有研究发现， 凯氏带可以出现在植物根的外皮层、茎的木栓细胞以 及针叶的内皮细胞等部位 ${ }^{[10 \sim 14]}$. 综上所述，凯氏带作 为一种特化的具有屏障功能的细胞壁结构, 在不同植 物甚至不同功能的细胞中具有一定的结构性差异.

\section{2 凯氏带的化学成分}

早在20世纪初, 通过组化的方法发现, 组成凯氏带 的主要成分是木质化物质。随后在长达半个多世纪的 时间里，研究者依托于生物技术的不断发展，利用不 同方法, 对不同植物中凯氏带的化学成分进行了分析.
研究发现, 凯氏带的主要成分可能是木质素、木栓 质、多糖类和氨基酸等物质, 并随物种、所在组织器 官的不同而呈现多态性. 但是其具体组成成分还存在 一定争议 ${ }^{[15]}$. 利用电子显微镜及傅里叶变换红外光谱 技术(Fourier transform infrared，FTIR)，发现君子兰 (Clivia miniata) 根部分离出来的凯氏带主要含有木质 素, 而对踠豆(Pisum sativum)根中分离的凯氏带进行 化学分析, 发现踠豆中木质素含量和木栓质含量相当. 1992年，Karahara和Shibaoka ${ }^{[16]}$ 利用酶解法从马铃薯 (Solanum tuberosum)的根部内皮层分离出凯氏带网络 结构, 这一方法的应用, 极大地推动了凯氏带化学成 分研究的进程.

近年来, 随着新技术的产生与发展, 凯氏带的主要 组成成分更加清晰. 2012年, Naseer等人 ${ }^{[4]}$ 通过组化分 析与染色等技术联用的方法，对拟南芥根中的凯氏带 进行研究, 发现早期形成的凯氏带已含有木质素, 但 没有木栓质的沉积，而成熟的凯氏带同时具有木质素 及木栓质两种组分. 该研究结果表明，拟南芥凯氏带 在不同发育阶段具有不同的主要成分. 在后来的实验 中, Geldner ${ }^{[17]}$ 发现, 凯氏带主要由木质素聚合物形成, 否定了长期以来认为凯氏带是由木栓质组成的观点. 他认为: (i) 之前研究者分离得到的凯氏带中含有内 皮层细胞, 而内皮层细胞中含有大量的木栓质物质, 进 而导致研究发现凯氏带成分中含有木栓质; (ii) 木栓 质物质是一种甘油酚-脂类聚合物, 其成分与细胞壁上 的蜡质组成类似, 它可以控制水分和溶质的流出, 更适 合作为水分和养分传输的屏障, 因此木栓质物质被认 为是凯氏带中对离子运输起阻滞作用的物质 ${ }^{[17]}$. 当然, 这一观点也存在不同的争议. 例如, 最近应用傅里叶变 换红外光谱技术和受激拉曼散射(stimulated raman scattering, SRS)技术对玉米的凯氏带成分进行分析, 结果显示, 玉米根部凯氏带中木质素和木栓质均存 在 $^{[18]}$ ，而且两种成分基本同时发育沉积，相似的结果 也在杉木中发现 ${ }^{[19]}$. 这些研究结果的不同, 可能是由 于植物种类及研究技术的差异而导致, 这为今后进一 步深入研究凯氏带的结构和功能提供了参考和依据.

\section{2 凯氏带的发育过程和生理功能}

\section{1 凯氏带的发育过程}

凯氏带是在内皮层发育过程中形成的规则或不规 

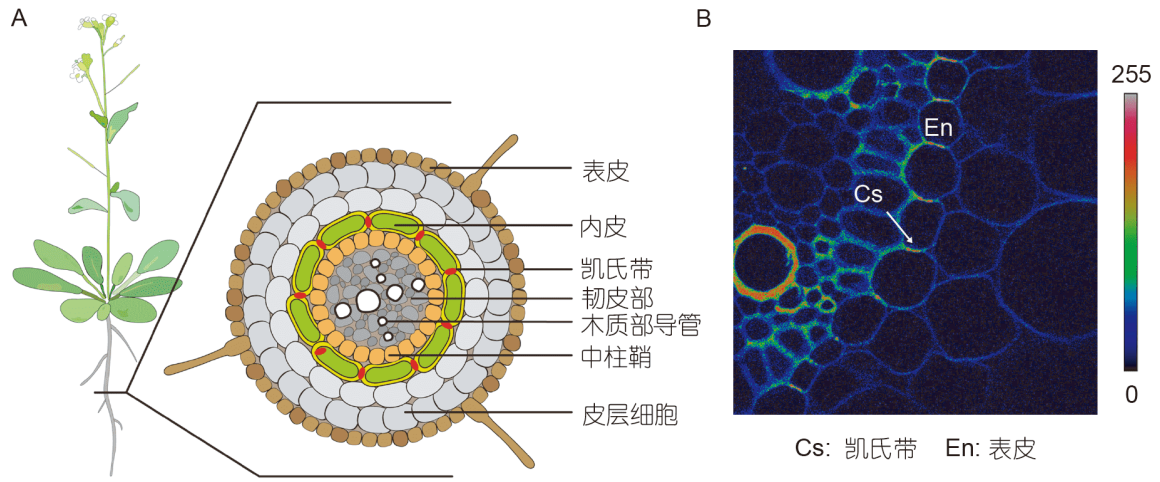

图 1 植物根系凯氏带的分布. A: 拟南芥初生根的横切面; B: 玉米初生根的横切面

Figure 1 Distribution of Casparian strips in plant roots. A: The diagrams depict primary root cross-sections of Arabidopsis thaliana; B: the diagrams depict primary root cross-sections of maize

则带状增厚结构 ${ }^{[20]}$. 目前的研究表明, 大多数植物的 内皮层发育分为 3 个阶段. 第一个阶段是初生阶段, 即 内皮层细胞的横向壁和径向壁出现凯氏带. 凯氏带先 在内皮层与中柱鞘细胞之间形成规则或不规则的带状 结构，此后在细胞生长过程中填充两个相邻内皮层细 胞(包括中间板层)之间的整个空间 ${ }^{[21]}$. 第二个阶段是 次生阶段，其特点是在细胞壁与质膜之间形成一层连 续的木栓层, 其木栓质的含量随着内皮层由初生阶段 发育到次生阶段而逐渐增加，发育成熟的木栓质通常 均匀沉积并包围整个内皮层细胞. 第三个阶段是三生 阶段，有一层厚厚的木质素沉积在内皮层的横、径向 壁上，并常常伴有木质化 ${ }^{[17,22]}$. 这一阶段细胞壁上木 质素的增厚可分为两种类型: 一类是 $\mathrm{O}$ 型增厚, 即木质 素均匀地沉积在细胞壁的周围; 另一类是 $C$ 型增厚, 即 内切壁上强烈增厚, 又称马蹄形或 $\mathrm{U}$ 形增厚 ${ }^{[23]}$. 值得注 意的是，凯氏带的发育情况与物种、根的生长状况以 及植物生长的环境等有密切关系.

之前的研究表明, 在拟南芥早期发育阶段, 凯氏带 先含有木质素, 而木栓质没有沉积, 但此时的凯氏带功 能已经完善, 即有屏障功能. 但在拟南芥发育后期, 凯 氏带中也存在木栓质的沉积 ${ }^{[4]}$. 而Man等人 ${ }^{[18]}$ 对玉米 根中凯氏带的研究表明，在凯氏带形成过程中，木质 素与木栓质基本同时出现沉积，即屏障功能建立时的 凯氏带既有木质素也有木栓质. 这些结果可能预示着 双子叶植物与单子叶植物的的凯氏带具有不同的发育 模式.

\section{2 凯氏带的生理功能}

植物根系吸收水分和矿质元素后，通常可以由细 胞壁和细胞间隙构成的质外体途径, 以及质膜和原生 质体构成的共质体途径进行运输. 而凯氏带的存在阻 抑了皮层与维管柱之间的质外体运输途径, 迫使水分 和离子通过共质体途径进入维管柱，从而实现离子的 选择性吸收 ${ }^{[24]}$. 但需要指出的是, 凯氏带对水分或者 离子并不是完全不透过的 ${ }^{[25]}$. 已有研究表明, 大多数 钠离子能够通过凯氏带进入水稻(Oryza sativa) 的茎 中, 即由于流体静压梯度引起溶于水的离子通过内、 外皮层初生细胞壁上的凯氏带进入到蒸腾流中 ${ }^{[26]}$. 另 外, Ma等人 ${ }^{[27]}$ 对水稻的研究表明, OsLsi1/2能够将根 外硅运输到质外体中, 然后通过质外体将硅转运到中 柱鞘中. 同时, 凯氏带还能阻碍经过共质体途径进入 维管柱的溶质倒流，从而保证植物各种生理代谢活动 在稳定的内环境中进行. 此外, 凯氏带的存在还能够 维持维管柱内的膨压. 尽管凯氏带阻碍了皮层与中柱 的物质交流，但内皮层细胞内形成的多个小孔成为水 分和矿质元素的新通道. 因此, 植物根系凯氏带的发 育既维持了根的吸收功能，又控制了水、离子和氧气 自由进出植物体, 从而保证生命活动的正常进行.

凯氏带可以调节或阻抑水分和离子运输, 进而对 非生物胁迫及生物胁迫中的植物起到保护作用. 通过 对环境胁迫下植物组织化学特性进行分析, 证明环境 胁迫可以促进凯氏带的形成 ${ }^{[15]}$, 如在盐胁迫 ${ }^{[28]}$ 或缺 氧 ${ }^{[29]}$ 条件下, 水稻的凯氏带会提早发育并变宽, 并且 
凯氏带形成细胞距根尖的距离变短. 相似的现象也在 棉花(Gossypium spp.)和玉米(Zea mays)等植物中观察 到 ${ }^{[30]}$. 此外, 在高盐胁迫下, 凯氏带能阻止盐分通过质 外体途径大量流入维管束，有效地保护内皮层的内部 组织, 减少高盐对植物的生理伤害 ${ }^{[31]}$. 值得注意的是, 有害离子的胁迫也能影响细胞的木栓质组成以及含 量. Cheng等人 ${ }^{[32]}$ 通过对红树林的根部进行锌离子处 理, 发现植物在抵御锌离子胁迫时, 根系外皮层细胞 通过细胞壁加厚以及木栓积累来减少有害离子的吸 收. Líška等人 ${ }^{[24]}$ 的研究表明, 在镉离子胁迫条件下, 玉 米根系细胞的木栓质组分发生变化，镉离子会造成玉 米接触区外皮层和内皮层结构的不对称发育，而且也 能造成外皮层细胞壁明显加厚并有大量木栓积累，减 少了根系对有害离子的吸收与运输. 此外, 一些研究 者也发现，激素或者小肽也可以影响凯氏带的形成， 进而影响离子的运输. 例如, Tao等人 ${ }^{[33]}$ 发现, 在东南 景天(Sedum alfredii)超积累型植物中, 低水平的脱落酸 抑制凯氏带的形成，使得镉离子通过质外体运输途径 进入木质部而大量富集. Nakayama等人 ${ }^{[34]}$ 的研究表 明，低表达量的维管束合成的小肽(CIF1和CIF2)能够 影响拟南芥根中凯氏带的形成, 并导致植物对铁的不 耐受. 此外, 研究也发现, 根毛和表皮的脱落能够促进 外皮层细胞外壁木栓加厚，进而抵御病原体和有害真 菌进入根系. 由此可见, 凯氏带很可能是在植物由水 生到陆生期间与外界环境相互作用的产物. 凯氏带的 出现使植物逐渐适应旱生环境, 并保护植物免受外来 胁迫的伤害以适应多变的外界环境.

\section{3 凯氏带形成的调控机制及相关的基因 家族}

早期对凯氏带的研究工作主要是围绕其物理结 构、化学成分和生长发育等方面. 虽然对于凯氏带的 构成和发育过程已经有了基本认识，但是对于凯氏带 形成的相关分子机制尚不清晰. 分子生物学以及遗传 学研究表明, 凯氏带的形成需要几个关键因子：（i ) 凯氏带膜蛋白家族(Casparian strip membrane domain protein, CASPs); (ii) 亮氨酸受体激酶(the GASSHO1/ SCHENGEN3, GSO1/SGN3); (iii) MYB36(MYB DOMAIN PROTEIN 36)转录因子. 下文对 3 个关键因子进 行详细介绍.

\subsection{CASPs}

CASPs 是第一个被鉴定的凯氏带膜蛋白家族, 它 精确定位在拟南芥根部内皮层凯氏带形成的位置上, 参与凯氏带的形成并帮助建立植物体内质外体运输的 屏障 ${ }^{[35]}$. 2011年, Roppolo等人 ${ }^{[36]}$ 以模式植物拟南芥为 材料, 首先发现了植物中CASPs蛋白的存在, 同时发现 拟南芥根中存在 5 个凯氏带蛋白CASP $1 \sim 5$, 并且这 5 个 凯氏带蛋白间存在功能性午余. 例如casp 1 或者 casp 3 单基因突变不会导致凯氏带的异常, 而双突变体 casp 1/casp3则表现出无法形成完整凯氏带的表型, 但 并不能改变凯氏带的阻滞功能. 因此, CASPs 家族对 凯氏带的形成起着重要的作用.

CASPs是一类跨膜蛋白，定位在内皮层细胞壁的 一个狭小区域，在凯氏带形成过程中起着结构框架的 作用. 在形成凯氏带的过程中, CASPs需要招募一些酶 和辅助因子，例如过氧化物酶64(peroxidase 64, PER64)、呼吸爆发氧化酶(respiratory burst oxidase homolog F, RBOHF)、增强子小栓质(enhanced suberin $1, \mathrm{ESB} 1$ )等, 它们共同参与凯氏带主要组成部分木质素 的合成, 并且这种影响是可逆的(图2 $)^{[37,38]}$. Lee等人 ${ }^{[39]}$ 的研究表明, NADPH氧化酶的一个家族成员RBOHF 的缺失能够显著延迟胼胝质的形成, 并最终导致木质 素的积累受到影响. 另外, 已有研究也表明, ESB1的缺 失会导致CASPs在凯氏带中的错误定位. 因为ESB1是 一个编码含有Dirigent结构域的蛋白质，该基因的缺失 会导致凯氏带变宽、形成延迟和根中木栓质增加，并 同时造成木质素的异位沉积 ${ }^{[40,41]}$. 总而言之, 这些研究 结果表明, CASPs在凯氏带的形成过程中起着脚手架 的作用(图2)，通过控制蛋白质之间直接或间接的相互 作用和相互影响, 最终调控凯氏带的形成.

\subsection{GSO1/SGN3}

除了CASPs以外, 凯氏带的合成还需要 GSO1和 SGN3一起参与. 已有研究表明, CASPs的准确定位受 两类在内皮层表达的受体激酶 GSO 1 和 $\mathrm{SGN} 3$ 的控 制 $^{[42,43]}$. GSO1/SGN3 基因编码富亮氨酸重复类受体激 酶(leucine-rich repeat receptor kinase, LRR-RK), 能够 在根的内皮层细胞中表达. 在 $g s o 1 / s g n 3$ 突变体中发现 植物CASPs的不正确定位, 最终使凯氏带呈不连续的 岛状排布, 从而难以形成连续的凯氏带环, 导致根中 


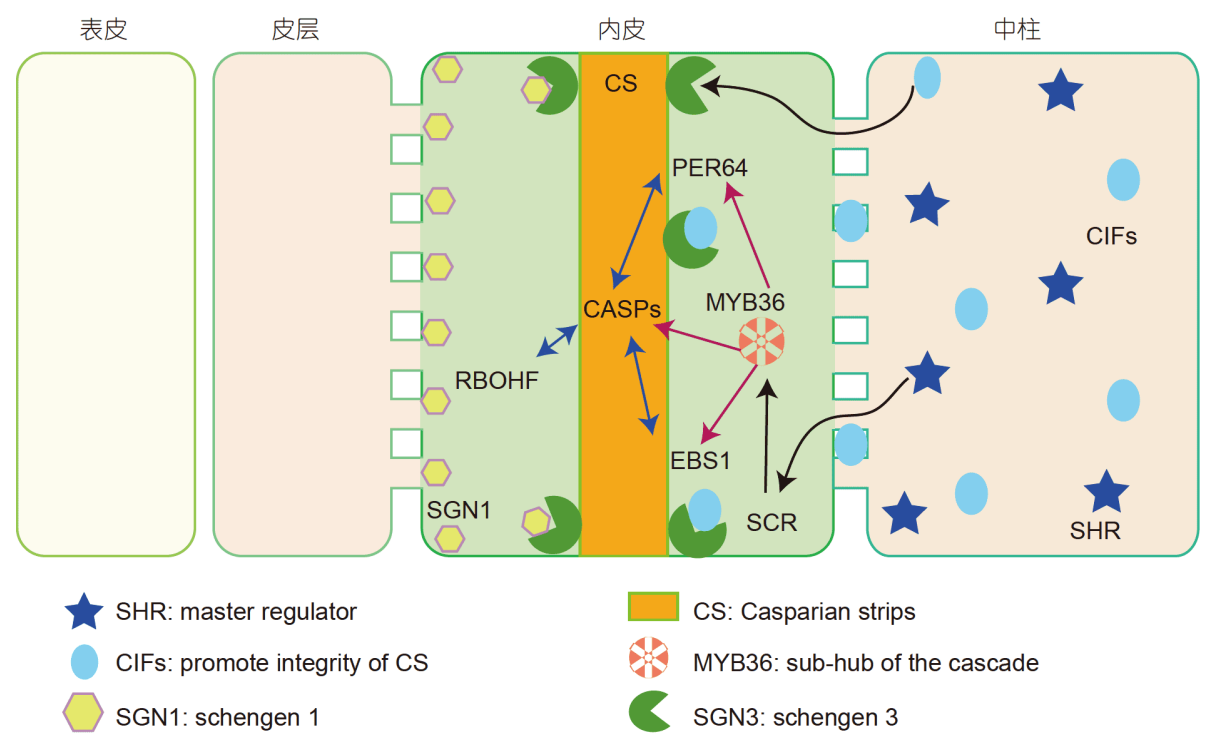

图 2 拟南芥根内皮层凯氏带形成调控机制模式图. 在凯氏带开始形成时, CASPs蛋白首先定位在内皮层细胞壁的中间, 形成 凯氏带的结构框架, 然后招募一些酶和辅助因子, 包括RBOHF, PER64和ESB1, 参与木质素的聚合. 受体激酶GSO1和SGN3的 作用是确保CASPs蛋白的准确定位和形成完整的复合体框架. MYB36作为凯氏带形成机制的一个主要调控者，能直接激活 RBOHF, PER64和ESB1

Figure 2 Summarized regulatory network of CS formation in Arabidopsis thaliana roots. Casparian strip formation is initiated by the localization of the CASPs in the plasma membrane, at the site where the Casparian strip will form. Localized CASPs recruit RBOHF PER64, ESB1 to assemble the lignin polymerization. The GSO1/SGN3 receptor activation is required for the positioning and correct formation of the centrally located CASP domain. Furthermore, MYB36 may induce a cofactor required for activation of RBOHF, PER64 and ESB1

难以产生有效的质外体运输 ${ }^{[33]}$. GSO1也称作 SGN1, Alassimone等人 ${ }^{[42]}$ 发现，SGN1除了是CASP结构域的 完整性和定位所必需的外，它还可以极性的方式在内 皮层细胞质膜上定位，并且通过棕榈酰化可逆地调控 这种定位. SGN3基因在内皮层分化早期被表达，也就 是早于CASPs 的基因表达，这能够影响凯氏带的建立 但不影响栓质的形成. 通过GSO1和SGN3的共定位实 验表明, GSO1和SGN3 具有部分共定位的现象，这也 就表明GSO1和SGN3存在部分独立的活性 ${ }^{[43]}$.

来自维管束合成的小肽 CIFs 能够特异性地与 GSO1/SGN3 基因结合，以促进形成完整的功能性凯氏 带. $\mathrm{Li}$ 等人 ${ }^{[44]}$ 在拟南芥根中发现，维管束的信号小肽 CIFs 在非内皮层细胞转变为功能性凯氏带内皮层细 胞的过程中起重要作用，而且他们也发现该调控机理 在番茄和大豆等作物中很可能也是保守的. 因此, GSO1/SGN3 是保证形成凯氏带完整空间结构的关键 因子.

\subsection{MYB36}

$M Y B 36$ 可以编码一个转录因子, 并且能够作为凯
氏带形成机制的一个主要调控因子. 2015年，Kamiya 等人 ${ }^{[37]}$ 研究发现, myb36突变体中凯氏带的合成受阻, 并被一种类似木质素的物质所替代. 此外, 研究也发 现, MYB36能调控下游大多数促进凯氏带形成相关基 因的表达，其中包含 $C A S P s, E S B 1$ 和PER64等基因(图 2). 并且需要指出的是, 过表达 $M Y B 36$ 后出现木质素 在其他细胞异位累积的现象. 同年, Liberman等人 ${ }^{[45]}$ 对拟南芥的研究也发现, MYB36的表达依赖于GRAS 家族的转录因子 SCARECROW (SCR), 而 $S C R$ 是 GRAS家族SHORTROOT(SHR)的直接靶基因，并且 也已证明SHR也能激活MYB36的表达. 总之, MYB36 能够调控拟南芥根系从增殖向分化的转变, 并协调凯 氏带的形成.

综合这些研究可知, 在凯氏带形成过程中, CASPs 蛋白首先为形成凯氏带建立一个平台，然后招募一些 酶和辅助因子, 例如RBOHF, PER64, ESB1等, 一起参 与木质素的聚合. 凯氏带合成平台的形成还需要其他 蛋白质, 包括受体激酶 GSO 1 和 SGN3, 它们能将 CASPs蛋白精确地定位到细胞壁的凯氏带形成点上, 确保形成完整的复合体框架. 此外, 转录因子MYB36 
作为凯氏带形成机制的一个主要调控者, 能够激活凯 氏带形成的关键基因的表达，例如CASPs，PER64， $E S B 1$ 等, 共同协助凯氏带的形成. 总之, 功能性凯氏带 的形成有两方面因素起着决定性作用，一方面是木质 素的累积, 而另一方面是凯氏带的精确定位. 在上述 基因的共同调控下，才能确保功能性凯氏带的形成和 精确的时空定位 ${ }^{[46]}$. 同时, 也启示人们在以后的研究 中, 可通过人为调控凯氏带的形成来调控植物根系对 养分的吸收, 进而改变植物在各种外界环境下的生长 及发育情况, 使其更有利于现代农林业生产.

\section{4 展望}

凯氏带是植物根系中的一道天然屏障, 可以阻抑 水分和矿质元素在植物根系内层细胞间的自由移动. 近年来, 研究人员进一步发现凯氏带还可能作为一个 信号平台来参与植物的生长发育 ${ }^{[47,48]}$. 随着一系列新 技术的研发与应用, 凯氏带的相关研究已经取得了重 大突破. 例如, 先前认为凯氏带仅在植物根部存在, 但 后来研究发现, 凯氏带也存在于针叶植物的针状叶内 皮层 ${ }^{[11,12]}$. 再者, 关于凯氏带的主要成分一直存在争 议，有的研究者认为凯氏带的主要成分是木质素，而 有的研究者认为是木栓质. 2012年, 研究人员在拟南 芥早期发育的凯氏带中只检测到了木质素, 而此时凯 氏带已有屏障功能 ${ }^{[4]}$; 而在拟南芥根发育后期的凯氏 带中会有木栓质的沉积. 基于拉曼散射原理的共聚焦 拉曼散射显微术及受激拉曼散射显微术的出现，极大 地推进了植物凯氏带的原位检测, 目前已应用于对不 同植物的不同发育阶段凯氏带的组分检测.
随着生物化学分析技术及遗传学研究方法的发 展, 前人的研究极大地增加了对凯氏带的理解, 人们对 凯氏带的研究也不断深入. 然而, 关于凯氏带的化学成 分、生理功能以及相关分子调控机制等方面仍然不清 晰. 譬如, 前期的研究表明, 凯氏带在响应非生物胁迫 方面有着重要的生理功能, 但是凯氏带是如何响应非 生物胁迫以及其分子调控机制还有待于进一步确定. 虽然前人对拟南芥根部凯氏带形成的分子机制有了部 分理解, 并鉴定到很多参与凯氏带和木质素合成的相 关基因，但这些基因在其他物种尤其是在树木中是否 以类似的方式调控凯氏带的形成还不清楚. 再者, 人 们普遍认为, 木质素是构成凯氏带的主要结构物质, 但组成凯氏带的木质素属于哪一类型，不同类型的木 质素单体在凯氏带组成中的作用, 以及不同单体的聚 合方式等都还模糊. 因此, 对凯氏带的研究仍然存在 很多空白, 仍需进一步研究.

拟南芥中关于凯氏带功能及分子机制的研究，将 极大地促进研究者对其他作物凯氏带生理功能的理 解, 为改良农林植物性状奠定了理论基础. 例如, 西瓜 的CASPs基因家族除了在凯氏带形成过程中发挥作用 外, 还在植物生长发育及环境胁迫响应过程中发挥重 要的功能, 这将有助于揭示西瓜凯氏带的形成机理并 指导培育优良品种 ${ }^{[49]}$. 与拟南芥类似, 番茄的 $S G N 3$ 和 MYB36基因发挥同样的作用, 调控凯氏带的形成, 这为 解析番茄凯氏带的功能和形成的分子机制提供了坚实 的基础 ${ }^{[46]}$. 因此, 详细阐明凯氏带发挥功能的分子调 控机制，对于通过利用生物工程手段进行农林植物性 状的改良具有深远的意义.

\section{参考文献}

1 Kalmbach L, Hématy K, De Bellis D, et al. Transient cell-specific EXO70A1 activity in the CASP domain and Casparian strip localization. Nat Plants, 2017, 3: 17058

2 Zelko I, Lux A, Sterckeman T, et al. An easy method for cutting and fluorescent staining of thin roots. Ann Bot, 2012, 110: 475-478

3 Lux A, Morita S, Abe J, et al. An improved method for clearing and staining free-hand sections and whole-mount samples. Ann Bot, 2005, 96: 989-996

4 Naseer S, Lee Y, Lapierre C, et al. Casparian strip diffusion barrier in Arabidopsis is made of a lignin polymer without suberin. Proc Natl Acad Sci USA, 2012, 109: 10101-10106

5 Fich E A, Segerson N A, Rose J K C. The plant polyester cutin: Biosynthesis, structure, and biological roles. Annu Rev Plant Biol, 2016, 67: 207233

6 Cui Y, Zhang X, Yu M, et al. Techniques for detecting protein-protein interactions in living cells: Principles, limitations, and recent progress. Sci 
China Life Sci, 2019, 62: 619-632

7 Parniske M. Arbuscular mycorrhiza: The mother of plant root endosymbioses. Nat Rev Microbiol, 2008, 6: 763-775

8 Alassimone J, Roppolo D, Geldner N, et al. The endodermis—-Development and differentiation of the plant's inner skin. Protoplasma, 2012, 249: $433-443$

9 Wong Q Q, Zheng X J, Jie H F, et al. Molecular mechanism of formation and function characteristics of Casparian strips (in Chinese). Acta Bot Boreal-Occident Sin, 2017, 37: 1450-1456 [翁群清, 郑秀娟, 解慧芳, 等. 植物凯氏带形成分子机制及功能特点的研究进展. 西北植物学报, 2017, 37: 1450-1456]

10 Meyer C J, Peterson C A. Casparian bands occur in the periderm of Pelargonium hortorum stem and root. Ann Bot, 2011, 107: 591-598

$11 \mathrm{Wu}$ X, Lin J, Lin Q, et al. Casparian strips in needles are more solute permeable than endodermal transport barriers in roots of Pinus bungeana. Plant Cell Physiol, 2005, 46: 1799-1808

12 Wu X Q, Zhang D X, Hu Y X, et al. The function of pinus bungeana foliar endodermis as apoplastic barrier under salt stress (in Chinese). J Trop Subtrop Bot, 2007, 15: 203-208 [吴小琴, 张奠湘, 胡玉喜, 等. 白皮松针叶内皮层在盐胁迫中的屏障作用研究. 热带亚热带植物学报, 2007, 15: 203-208]

13 Tang X, Wu X Q, Lü H F, et al. Occurrence of Casparian strips in the leaf endodermis of 10 genera of pinaceae (in Chinese). J Chin Elect Microsc Soc, 2004, 23: 560-565 [唐熙, 吴小琴, 吕洪飞, 等. 松科10属植物叶子内皮层具有凯氏带的新证据. 电子显微学报, 2004, 23: 560-565]

14 Tang X, Wu X Q, Hu Y X, et al. Comparative study of Casparian strips in the roots and needles of Pinus armandi (in Chinese). Acta Bot BorealOccident Sin, 2004, 24: 1378-1383 [唐熙, 吴小琴, 胡玉喜, 等. 华山松根与针叶凯氏带的比较研究. 西北植物学报, 2004, 24: 1378-1383]

15 Chen T, Cai X, Wu X, et al. Casparian strip development and its potential function in salt tolerance. Plant Signal Behav, 2011, 6: 1499-1502

16 Karahara I, Shibaoka H. Isolation of Casparian strips from pea roots. Plant Cell Physiol. 1992, 33: 555-561

17 Geldner N. The endodermis. Annu Rev Plant Biol, 2013, 64: 531-558

18 Man Y, Zhao Y, Ye R, et al. In vivo cytological and chemical analysis of Casparian strips using stimulated Raman scattering microscopy. J Plant Physiol, 2018, 220: 136-144

19 Song C, Shen W, Du L, et al. Development and chemical characterization of Casparian strips in the roots of Chinese fir (Cunninghamia lanceolata). Trees, 2019, 33: 827-836

20 Alassimone J, Naseer S, Geldner N. A developmental framework for endodermal differentiation and polarity. Proc Natl Acad Sci USA, 2010, 107: 5214-5219

21 Wu X Q, Zhu J M, Wang Q L, et al. Advances in studies on Casparian strips (in Chinese). Chin Bull Bot, 2002, 19: 302-309 [吴小琴, 朱锦森, 王 钦丽, 等. 植物凯氏带的研究进展. 植物学报, 2002, 19: 302-309]

22 White P J. The pathways of calcium movement to the xylem. J Exp Bot, 2001, 52: 891-899

23 Cai X, Wu X Q, Zhou Q Y, et al. Endodermal Casparian strips and its role in adaptation to salt stress (in Chinese). J Chin Elect Microsc Soc, 2011, 30: 533-540 [蔡霞, 吴小琴, 周庆源, 等. 植物内皮层凯氏带及其在抗盐胁迫中的作用. 电子显微学报, 2011, 30: 533-540]

24 Líška D, Martinka M, Kohanová J, et al. Asymmetrical development of root endodermis and exodermis in reaction to abiotic stresses. Ann Bot, 2016, 118: 667-674

25 Ranathunge K, Steudle E, Lafitte R. A new precipitation technique provides evidence for the permeability of Casparian bands to ions in young roots of corn (Zea mays L.) and rice (Oryza sativa L.). Plant Cell Environ, 2005, 28: 1450-1462

26 Krishnamurthy P, Ranathunge K, Nayak S, et al. Root apoplastic barriers block Na ${ }^{+}$transport to shoots in rice (Oryza sativa L.). J Exp Bot, 2011, 62: 4215-4228

27 Ma J F, Yamaji N, Mitani N, et al. An efflux transporter of silicon in rice. Nature, 2007, 448: 209-212

28 Krishnamurthy P, Ranathunge K, Franke R, et al. The role of root apoplastic transport barriers in salt tolerance of rice (Oryza sativa L.). Planta, 2009, 230: 119-134

29 Kotula L, Ranathunge K, Schreiber L, et al. Functional and chemical comparison of apoplastic barriers to radial oxygen loss in roots of rice (Oryza sativa L.) grown in aerated or deoxygenated solution. J Exp Bot, 2009, 60: 2155-2167

30 Wang P, Chen N L, Zou X H, et al. Research progress on adaptive responses of anatomical structure of plant roots to stress (in Chinese). Chin J Ecol, 2015, 34: 550-556 [汪攀, 陈奶莲, 邹显花, 等. 植物根系解剖结构对逆境胁迫响应的研究进展. 生态学杂志, 2015, 34: 550-556]

31 Karahara I, Ikeda A, Kondo T, et al. Development of the Casparian strip in primary roots of maize under salt stress. Planta, 2004, 219: 41-47

32 Cheng X, Huang X, Wang X, et al. Influence of calcination on the adsorptive removal of phosphate by Zn-Al layered double hydroxides from 
excess sludge liquor. J Hazard Mater, 2010, 177: 516-523

33 Tao Q, Jupa R, Liu Y, et al. Abscisic acid-mediated modifications of radial apoplastic transport pathway play a key role in cadmium uptake in hyperaccumulator Sedum alfredii. Plant Cell Environ, 2019, 42: 1425-1440

34 Nakayama T, Shinohara H, Tanaka M, et al. A peptide hormone required for Casparian strip diffusion barrier formation in Arabidopsis roots. Science, 2017, 355: 284-286

35 Yang C D, Zhang X, Liu G F, et al. Progress on the structure and physiological functions of apoplastic barriers in root (in Chinese). Bull Bot Res, 2013, 33: 114-119 [杨朝东, 张霞, 刘国锋, 等. 植物根中质外体屏障结构和生理功能研究进展. 植物研究, 2013, 33: 114-119]

36 Roppolo D, De Rybel B, Dénervaud Tendon V, et al. A novel protein family mediates Casparian strip formation in the endodermis. Nature, 2011, 473: $380-383$

37 Kamiya T, Borghi M, Wang P, et al. The MYB36 transcription factor orchestrates Casparian strip formation. Proc Natl Acad Sci USA, 2015, 112: $10533-10538$

38 Li P X. The regulation of endodermis-specific Casparian strips in tomato roots (in Chinese). Dissertation for Master's Degree. Fuzhou: Fujian Agricultural and Forestry University, 2018 [李朋雪. 番茄根系内皮层凯氏带调控机制的研究. 硕士学位论文. 福州: 福建农林大学, 2018]

39 Lee Y, Rubio M C, Alassimone J, et al. A mechanism for localized lignin deposition in the endodermis. Cell, 2013, 153: 402-412

40 Hosmani P S, Kamiya T, Danku J, et al. Dirigent domain-containing protein is part of the machinery required for formation of the lignin-based Casparian strip in the root. Proc Natl Acad Sci USA, 2013, 110: 14498-14503

41 Gao L, Yang H L, Wang P, et al. Suberin and its physiological function (in Chinese). Pratacult Sci, 2018, 298: $284-297$ [高丽, 杨海莉, 王沛, 等. 木栓质及其生理功能. 草业科学, 2018, 298: 284-297]

42 Alassimone J, Fujita S, Doblas V G, et al. Polarly localized kinase SGN1 is required for Casparian strip integrity and positioning. Nat Plants, 2016, 2: 1

43 Pfister A, Barberon M, Alassimone J, et al. A receptor-like kinase mutant with absent endodermal diffusion barrier displays selective nutrient homeostasis defects. eLife, 2014, 3: e03115

44 Li P, Yu Q, Gu X, et al. Construction of a functional Casparian strip in non-endodermal lineages is orchestrated by two parallel signaling systems in Arabidopsis thaliana. Curr Biol, 2018, 28: 2777-2786.e2

45 Liberman L M, Sparks E E, Moreno-Risueno M A, et al. MYB36 regulates the transition from proliferation to differentiation in the Arabidopsis root. Proc Natl Acad Sci USA, 2015, 112: 12099-12104

46 Li P, Yang M, Chang J, et al. Spatial expression and functional analysis of Casparian strip regulatory genes in endodermis reveals the conserved mechanism in tomato. Front Plant Sci, 2018, 9

47 Dinneny J R. A gateway with a guard: How the endodermis regulates growth through hormone signaling. Plant Sci, 2014, 214: 14-19

48 Robbins N E, Trontin C, Duan L, et al. Beyond the barrier: Communication in the root through the endodermis. Plant Physiol, 2014, 166: 551559

49 Yang J, Ding C, Xu B, et al. A Casparian strip domain-like gene, CASPL, negatively alters growth and cold tolerance. Sci Rep, 2015, 5: 14299 


\title{
Chemical components, physiological functions and regulation mechanism of plant Casparian strips
}

\author{
CUI YaNing ${ }^{1,2}$, MAN Yi ${ }^{1,2}$, SONG ChengWei ${ }^{1,2}$, ZHANG Xi $^{1,2}$, QIAN HongPing ${ }^{1,2}$ \& LIN \\ JinXing ${ }^{1,2}$
}

1 Beijing Advanced Innovation Center for Tree Breeding by Molecular Design, Beijing Forestry University, Beijing 100083, China; 2 College of Biological Sciences and Technology, Beijing Forestry University, Beijing 100083, China

Casparian strips are diagnostically modified structure mainly appeared in the endodermis, in which the radial parts of the cell walls are characterized by the deposition of lignin and suberin in the primary cell wall. As a barrier to the apoplastic movement of solutes from the cortex to the stele, Casparian strips are essential for the exclusion of salts and pathogens, selective nutrient uptake, and many other processes. With the development of biochemical analysis techniques and genetic research methods, the research in Casparian strips was increasing and has accumulated a large number of data. In this paper, we summarize the research progress in cytological structure, development processes, chemical components of Casparian strips. We focus in particular on recent advances in physiological functions and the regulation mechanism of Casparian strips during developmental processes and the response to different environmental conditions. This review can provide significant information for further investigation on the development of Casparian strips.

\section{Casparian strip, chemical components, physiological function, regulation mechanism}

doi: $10.1360 / \mathrm{SSV}-2019-0205$ 